\title{
A single blind active controlled study to compare the efficacy of microneedling and microneedling with 5 -flurouracil in treatment of stable vitiligo
}

\author{
Pojedynczo zaślepione badanie porównujące skuteczność mikronakłuwania \\ w monoterapii z mikronakłuwaniem w skojarzeniu z 5-flurouracylem w leczeniu \\ stabilnego bielactwa nabytego
}

Shishira R. Jartarkar, Kadnur G. Manjunath, Shivanna Harini, Shalini Sampath

Department of Dermatology, Vydehi Institute of Medical Sciences and Research Center, Whitefield Bangalore Karnatake, India

Klinika Dermatologii, Vydehi Institute of Medical Sciences and Research Center, Whitefield Bangalore Karnatake, Indie

Dermatol Rev/Przegl Dermatol 2021, 108, 275-284

DOI: https://doi.org/10.51/4/dr.2021.111306

\author{
CORRESPONDING AUTHOR/ \\ ADRES DO KORESPONDENCJI: \\ Dr. Shishira R. Jartarkar \\ Department of Dermatology \\ Vydehi Institute of \\ Medical Sciences and \\ Research Center \\ Whitefield Bangalore, Indie \\ E-mail: dr.shishira@gmail.com
}

\begin{abstract}
Introduction: Microneedling, a tool for transdermal delivery of drugs, improves the skin permeability to various therapeutic agents. 5-fluorouracil is a chemotherapeutic agent, a pyrimidine analogue, used in various combination chemotherapy regimens. It has been noticed that following topical 5-fluorouracil cream application, patients developed localized hyperpigmentation and this has gained the attention towards use of 5-fluorouracil in repigmentation of vitiliginous patches.
\end{abstract}

Objective: To assess the effectiveness of topical 5-fluorouracil following microneedling and to compare its results with microneedling alone in patients with stable vitiligo.

Material and methods: Forty patients with localized stable vitiligo were randomly divided into 2 groups of 20 each. In group A, patients were treated with microneedling alone and in group B, microneedling was followed by 5-flurouracil cream application every two weeks for 2 months and patients were followed up for 4 months after the last session. Repigmentation was assessed by grades ranging from grade 0 (G0) as no response to $\mathrm{G} 4$ as excellent response with $>75 \%$ repigmentation and any side effects were noted.

Results: Microneedling followed by 5-fluorouracil application showed better response than needling alone with minimal side effects and the results were statistically significant.

Conclusions: Microneedling with 5-fluorouracil yields positive therapeutic results in localized stable vitiligo.

Key words: microneedling, 5-fluorouracil, vitiligo.

\section{STRESZCZENIE}

Wprowadzenie: Mikronakłuwanie skóry (microneedling) jest techniką, która poprawia przenikanie przez skórę różnych środków terapeutycznych. 5-fluorouracyl jest chemioterapeutykiem z grupy analogów pirymidyn, wykorzystywanym jako jeden ze składników chemioterapii skojarzonej. Zaobserwowano, że po miejscowej aplikacji kremu zawierającego 5-fluorouracyl u pacjentów wystąpiła miejscowa hiperpigmen- 
tacja. Zwróciło to uwagę na możliwość stosowania 5-fluorouracylu jako leku indukującego repigmentację ognisk odbarwienia w bielactwie.

Cel pracy: Ocena skuteczności leczenia stabilnego bielactwa nabytego mikronakłuwaniem w skojarzeniu z 5-fluorouracylem.

Materiał i metody: Czterdziestu pacjentów ze stabilnym bielactwem podzielono losowo na 2 grupy po 20 osób. U pacjentów w grupie A wykonywano wyłącznie mikronakłuwanie. W grupie B po mikronakłuwaniu dodatkowo aplikowano na skórę krem z 5-fluorouracylem co 2 tygodnie przez łącznie 2 miesiące. Obserwację prowadzono do 4 miesięcy po ostatnim zabiegu. Stopień repigmentacji oceniano w skali od G0 (brak odpowiedzi) do G4 (> 75\% repigmentacji). Analizowano ewentualne działania niepożądane.

Wyniki: Lepszą odpowiedź na leczenie zaobserwowano w grupie, w której stosowano mikronakłuwanie oraz aplikowano krem z 5-fluorouracylem, niż w grupie, w której u pacjentów wykonywano wyłącznie mikronakłuwanie. Wyniki były znamienne statystycznie.

Wnioski: Mikronakłuwanie w skojarzeniu z 5-fluorouracylem może być skuteczną metodą leczenia bielactwa.

Słowa kluczowe: mikronakłuwanie, 5-fluorouracyl, bielactwo.

\section{INTRODUCTION}

Microneedling, also known as collagen induction treatment involves use of sterilized microneedles to puncture the skin repetitively [1]. It offers a relatively low cost and minimal invasive tool in multiple dermatologic conditions. The trauma generated by needle penetration into the skin induces dermal regeneration [2]. There is formation of multiple small holes called microconduits when the needles penetrate stratum corneum, with minimal epidermal damage, leading to release of growth factors like transforming growth factor a and $\beta$, platelet derived growth factors that in turn stimulate collagen and elastin production in the dermis [3].

Vitiligo, challenged by social outcast and stigma, results in predominant psychosocial burden in affected patients, hence, it is "not just a cosmetic disorder" [4, 5]. Various treatment modalities have been used with varying rates of repigmentation, with no single satisfactory/appealing treatment for vitiligo $[6,7]$. The recent use of needles has shown favorable degrees of repigmentation [8] and this physical trauma can be done using simple injection needles or microneedling devices like dermaroller, automated dermapen and microneedling radiofrequency devices. Microneedling is superior to simple injection needles as it controls the depth of penetration and maintains uniformity and also reduces the pain during injection [9]. It produces micro-inflammation in the epidermal layers, which stimulates and enhances the melanocytes and keratinocytes to migrate and help in vitiligo repigmentation [10]. Epidermal injury caused by microneedles

\section{WPROWADZENIE}

Mikronakłuwanie (microneedling), nazywane także przezskórną indukcją kolagenu, jest techniką polegającą na wielokrotnym nakłuwaniu skóry przy użyciu wysterylizowanych mikroigieł [1]. Jest to technika stosunkowo niedroga i minimalnie inwazyjna, stosowana w leczeniu wielu schorzeń dermatologicznych. Uraz wywołany nakłuwaniem pobudza proces regeneracji skóry [2]. Mikroigły przenikają przez warstwę rogową naskórka i przy minimalnym uszkodzeniu naskórka powstają liczne mikrokanaliki. Prowadzi to do uwalniania czynników wzrostu, takich jak transformujący czynnik wzrostu a i $\beta$, a także płytkopochodne czynniki wzrostu, które pobudzają wytwarzanie kolagenu i elastyny w skórze właściwej [3].

Bielactwo nabyte może się wiązać z wykluczeniem społecznym i stygmatyzacją, co wywołuje u pacjentów znaczące obciążenie psychospołeczne. $Z$ tego względu bielactwa nie należy postrzegać jako zaburzenia o charakterze wyłącznie kosmetycznym [4,5]. W leczeniu bielactwa nabytego stosuje się różne metody zapewniające zróżnicowany stopień repigmentacji, jednak nie ma dotąd jednej zadowalającej lub skutecznej metody terapii tego schorzenia [6, 7]. Ostatnio korzystny stopień repigmentacji obserwowano po zabiegach nakłuwania skóry [8]. Ten rodzaj mikrourazu można wytworzyć za pomocą zwykłych igieł iniekcyjnych lub urządzeń do terapii mikroigłowej, takich jak dermaroller, zautomatyzowany aparat typu dermapen lub urządzenia do mikronakłuwania wykorzystujące prąd o częstotliwości radiowej. Mikronakłuwanie ma przewagę nad zwykły- 
releases potassium and proteins inside the epidermal cells, hence reducing electric potential and increasing the potential difference between interior and exterior of the cell which triggers fibroblast migration to the injury site and helps in collagen remodeling [3]. Microneedling also acts as a tool for transdermal delivery of drugs as they create micropores in the epidermis, which helps improve the skin permeability to various therapeutic agents [11].

5-fluorouracil (5FU) is a chemotherapeutic agent, a pyrimidine analogue, used in various combination chemotherapy regimens. It has been noticed that following topical 5FU cream application, a patient developed localized hyperpigmentation and this has gained the attention towards use of 5FU in repigmentation of vitiliginous patches [12].

\section{OBJECTIVE}

The aim of this study is to assess the effectiveness of topical 5FU following microneedling and to compare its results with microneedling alone in patients with stable vitiligo.

\section{MATERIAL AND METHODS}

\section{Study design}

This was a hospital-based single blinded comparative interventional study conducted in the outpatient Department of Dermatology over a period from June 2018 to January 2020, after obtaining clearance from the institutional ethics committee.

\section{Patients}

A total of 40 patients of localized stable vitiligo were included in the study. Written informed consent was obtained from each participant before the study initiation. The study included patients in the age group of $15-60$ years with stable vitiligo patches $<10 \mathrm{~cm}$ and $<3$ in number. Stability was defined as no new patches or no change in the size or pigmentation of the existing patches and no koebnerization for a period of 6 months. Patients with mucosal vitiligo, active infection, keloidal or hypertrophic scar tendency, pregnant and lactating mothers, uncontrolled systemic illness and those with unrealistic expectations were excluded from the study. All patients were subjected to detailed history taking and cutaneous examination. Laboratory investigations such as complete hemogram, bleeding time and clotting time were performed in every patient.

Patients were randomly assigned into two groups of 20 each using "chit in the box" method. A single patch of less than $10 \mathrm{~cm}$ was selected in each patient for the study. mi igłami iniekcyjnymi, ponieważ umożliwia kontrolę głębokości penetracji naskórkowej i zapewnia spójny przebieg zabiegu, a także obniża dolegliwości bólowe związane z nakłuwaniem [9]. Wywołuje proces mikrozapalny w warstwach naskórka, pobudzając i nasilając migrację melanocytów i keratynocytów, która sprzyja repigmentacji [10]. Uraz naskórka spowodowany przez mikroigły uwalnia potas i białka wewnątrz komórek naskórka, co obniża potencjał elektryczny i zwiększa różnicę potencjałów między wnętrzem a zewnętrzem komórki. Wyzwala to proces przemieszczania się fibroblastów do miejsca urazu i przyczynia się do przebudowy kolagenu [3]. Mikronakłuwanie skóry jest także techniką stosowaną przy przezskórnym podawaniu leków. Powoduje powstanie w skórze mikroporów, które umożliwiają lepsze przenikanie przez skórę różnych środków terapeutycznych [11].

5-fluorouracyl (5FU) jest chemioterapeutykiem z grupy analogów pirymidyn wykorzystywanym jako jeden ze składników w różnych schematach chemioterapii skojarzonej. Zauważono, że po miejscowej aplikacji kremu zawierającego 5FU u pacjenta wystąpiła miejscowa hiperpigmentacja. Zwróciło to uwage na możliwość stosowania 5FU jako leku pobudzającego proces repigmentacji plam bielaczych [12].

\section{CEL PRACY}

Celem pracy jest ocena skuteczności 5FU stosowanego miejscowo na skórę po mikronakłuwaniu i porównanie wyniku tych zabiegów z mikronakłuwaniem w grupie pacjentów z bielactwem nabytym o stabilnym przebiegu.

\section{MATERIAŁ I METODY}

\section{Schemat badania}

W szpitalnej poradni dermatologicznej od czerwca 2018 do stycznia 2020 roku przeprowadzono porównawcze badanie interwencyjne $z$ pojedynczym zaślepieniem. Przed rozpoczęciem badania uzyskano zgodę odpowiedniej komisji bioetycznej.

\section{Pacjenci}

Do badania włączono 40 pacjentów z ograniczonym bielactwem nabytym o stabilnym przebiegu. Przed rozpoczęciem badania od każdego uczestnika uzyskano pisemną świadomą zgodę na udział. Do badania włączono pacjentów w wieku 15-60 lat. Liczba plam bielaczych u uczestników badania wynosiła $<3$, a plamy miały wielkość $<10 \mathrm{~cm}$. Stabilny przebieg choroby definiowano jako brak nowych ognisk lub brak zmian w wielkości lub stopniu pigmentacji istniejących zmian skórnych oraz brak zjawiska koebneryzacji przez 6 miesięcy. Z udziału w badaniu wyłączono pacjentów z bielactwem w obrę- 


\section{Group A}

The patch was anesthetized by application of topical lignocaine cream for an hour under occlusion and then the area was cleansed with povidone iodine and spirit. Microneedling was performed using a dermaroller with needle thickness of $1.5 \mathrm{~mm}$ by rolling side to side and up and down till multiple tiny punctate bleeding points appear. The area was then dressed with normal saline soaked gauze.

\section{Group B}

The same procedure was followed as in group A until multiple tiny bleeding points appear. This was followed by application of uniform thin layer of $5 \%$ FU cream and occlusive dressing was done and kept for a day.

Patients in both groups were advised to avoid use of any topical irritants or sunscreen usage in the immediate postoperative period. The session was repeated every fortnightly for four sessions and patients were followed up for 4 months. Any sideeffects noted were recorded.

\section{Assessment of improvement}

The improvement was assessed based on the degree of repigmentation and graded [12] (table 1) as grade (G) 0, G1, G2, G3, or G4.

G3 and above was considered as favorable outcome. The patients were photographed at baseline, after each session and at the end of 6 months.

\section{Statistical analysis}

Data were analyzed using SPSS version 19 and represented as frequency and percentage for categorical variables, mean and standard deviation for quantitative variables. $t$-test and $\chi^{2}$ tests were used. $P<0.05$ was considered statistically significant.

\section{RESULTS}

In both group $\mathrm{A}$ and $\mathrm{B}$, patients were comparable with respect to age and sex distribution with $p>0.05$. The mean age in group A was $33.4 \pm 10.2$ yrs and in group B was $31.7 \pm 10.1$ years (table 2 ). In our study, vitiligo was found to be more prevalent in females in both group A (60\%) and B (65\%). The most common site of involvement was extremities in both group A (55\%) and B (65\%), followed by head and neck and trunk.

\section{Evaluation of response}

In group A, repigmentation was noted in 75\% (15) out of which good response was noted in 30\% (6) and poor response noted in $45 \%$ (9) and no repigmentation was noted in $25 \%$ (5). bie błon śluzowych, czynnym zakażeniem, tendencją do przerostu blizn i powstawania bliznowców, niedostatecznie kontrolowaną chorobą ogólnoustrojową, a także kobiety w ciąży i karmiące piersią oraz osoby z nierealistycznymi oczekiwaniami dotyczącymi efektu leczenia. Od wszystkich pacjentów zebrano szczegółowy wywiad. Przeprowadzono także badanie dermatologiczne. U każdego uczestnika wykonano badania laboratoryjne, m.in. morfologię krwi oraz oznaczenie czasu krwawienia i krzepnięcia.

Pacjenci zostali poddani randomizacji do jednej z dwóch grup (A i B) liczących 20 osób przy zastosowaniu metody losowania (chit in the box). U każdego uczestnika wybrano pojedynczą plamę bielaczą o wielkości poniżej $10 \mathrm{~cm}$.

\section{Grupa A}

U każdego pacjenta plamę wybraną do zabiegu znieczulano poprzez miejscową aplikację kremu z lignokainą oraz założenie opatrunku okluzyjnego (na 1 godzinę). Następnie powierzchnię oczyszczano jodopowidonem i spirytusem salicylowym. Mikronakłuwanie wykonywano za pomocą dermarollera o grubości igieł 1,5 mm. Dermaroller przesuwano po skórze od lewej strony do prawej oraz z góry na dól, aż do pojawienia się punkcikowatego krwawienia. Następnie miejsce zabiegu zaopatrywano gazą nasączoną roztworem soli fizjologicznej.

\section{Grupa B}

W grupie B wykonywano zabieg według tej samej procedury jak w grupie A aż do wystąpienia punkcikowatego krwawienia. Następnie na miejsce poddane mikronakłuwaniu aplikowano jednolitą, cienką warstwę kremu z 5\% 5FU i zakładano opatrunek okluzyjny na 1 dzień.

Pacjentom w obu grupach zalecono unikanie miejscowych środków drażniących i preparatów przeciwsłonecznych bezpośrednio po zabiegu. Zabieg powtarzano co 2 tygodnie. Każdy pacjent odbył łącznie 4 zabiegi. Czas obserwacji wynosił 4 miesiące. Stwierdzono ewentualne działania niepożądane.

\section{Ocena poprawy stanu skóry}

Poprawę stanu skóry oceniano na podstawie stopnia repigmentacji (G) [12] (tab. 1) w skali od G0 do G4.

Wynik G3 i G4 oznaczał korzystny efekt leczenia. Leczone miejsca fotografowano na początku badania, po każdym zabiegu i po 6 miesiącach.

\section{Analiza statystyczna}

Dane poddano analizie przy użyciu programu SPSS w wersji 19 i wyrażono w postaci częstości i odsetków dla zmiennych kategorycznych oraz średnich i odchylenia standardowego dla zmiennych ilościowych. Zasto- 
Table I. Grading of repigmentation

Tabela I. Ocena stopnia repigmentacji

\begin{tabular}{|c|c|c|}
\hline $\begin{array}{l}\text { Repigmentation/ } \\
\text { Repigmentacja }\end{array}$ & $\begin{array}{l}\text { Grade/ } \\
\text { Stopień }\end{array}$ & $\begin{array}{c}\text { Response/Odpowiedź } \\
\text { na leczenie }\end{array}$ \\
\hline Absent/Brak & G0 & No respose/Brak \\
\hline$<25 \%$ & GI & Poor/Staba \\
\hline $25-50 \%$ & G2 & Good/Dobra \\
\hline $51-75 \%$ & G3 & Very good/Bardzo dobra \\
\hline$>75 \%$ & G4 & Excellent/Doskonała \\
\hline
\end{tabular}

Table 3. Treatment outcome of the study group after 6 months

Tabela 3. Wyniki leczenia w grupie badanej po 6 miesiącach

\begin{tabular}{lccc}
$\begin{array}{l}\text { Response on the } \\
\text { patches/Odpowiedź na } \\
\text { leczenie w obrębie plam }\end{array}$ & $\begin{array}{c}\text { Group A/ } \\
\text { Grupa A }\end{array}$ & $\begin{array}{c}\text { Group B/ } \\
\text { Grupa B }\end{array}$ & $\begin{array}{c}\text { P-value/ } \\
\text { Wartośćp }\end{array}$ \\
\hline G0 & $5(25 \%)$ & $0(0)$ & $<0.00$ I \\
\hline G1 & $9(45 \%)$ & $3(15 \%)$ & \\
\hline G2 & $6(30 \%)$ & $5(25 \%)$ & \\
\hline G3 & 0 & $7(35 \%)$ & \\
\hline G4 & 0 & $5(25 \%)$ & \\
\hline
\end{tabular}

In group $B$, all the patients noted repigmentation of varying grades. Favorable outcome (G3, G4) was noted in $60 \%$ (12) with excellent response noted in $25 \%$ (5) and very good response noted in $35 \%$ (7) (table 3). The difference in the improvement between the two groups was statistically significant with $p<0.001$.

\section{Side effects}

In group A, 20\% (4) of patients complained of pain during the procedure and erythema was noted in 35\% (7) which resolved spontaneously in next 3 days. In group B, all patients complained of pain during the procedure, erythema was noted in $70 \%$ (14), itching in $15 \%$ (3) and koebnerization was noted in 5\% (1) (table 4 , figures 1-4).

\section{DISCUSSION}

Vitiligo has a significant psychological impact on life resulting in low self-esteem [13]. $10 \%$ of the patients with vitiligo suffered depression as evidenced in an Indian study of 30 patients [14]. Hence, it is important to provide them with the most suitable costeffective treatment modality with acceptable results and help them improve their self-esteem. The suitable therapeutic modality has to be chosen from the vast armamentarium based on the stability and nature of the disease, extent of involvement, age and so on.

Microneedling (therapeutic wounding) has been used as a treatment option for various dermatoses. It has also been used as a transdermal drug delivery
Table 2. Demographic data of the study group

Tabela 2. Dane demograficzne pacjentów w badanych grupach

\begin{tabular}{|c|c|c|c|}
\hline $\begin{array}{l}\text { Clinical data/ } \\
\text { Dane kliniczne }\end{array}$ & $\begin{array}{l}\text { Group A/ } \\
\text { Grupa A }\end{array}$ & $\begin{array}{l}\text { Group B/ } \\
\text { Grupa B }\end{array}$ & $\begin{array}{l}\text { P-value/ } \\
\text { Wartość } p\end{array}$ \\
\hline $\begin{array}{l}\text { Age (mean } \pm \text { SD) [years]/ } \\
\text { Wiek (średnia } \pm \text { SD) [lata] }\end{array}$ & $\begin{array}{l}33.40 \\
\pm 10.216\end{array}$ & $\begin{array}{l}31.70 \\
+10.064\end{array}$ & \\
\hline \multicolumn{4}{|l|}{ Gender/Płeć: } \\
\hline Male/Mężczyzna & $8(40 \%)$ & $7(35 \%)$ & 0.744 \\
\hline Female/Kobieta & $12(60 \%)$ & $13(65 \%)$ & \\
\hline \multicolumn{4}{|l|}{ Type of vitiligo/Typ bielactwa: } \\
\hline $\begin{array}{l}\text { Non-segmental, generalized/ } \\
\text { Niesegmentalne, uogólnione }\end{array}$ & $9(45 \%)$ & $9(45 \%)$ & 0.767 \\
\hline Unclassified/Niesklasyfikowane & $7(35 \%)$ & $7(35 \%)$ & \\
\hline $\begin{array}{l}\text { Non-segmental, acral/ } \\
\text { Niesegmentalne, akralne }\end{array}$ & $4(20 \%)$ & $3(15 \%)$ & \\
\hline $\begin{array}{l}\text { Non-segmental, head and neck/ } \\
\text { Niesegmentalne, głowa i szyja }\end{array}$ & 0 & I (5\%) & \\
\hline \multicolumn{4}{|l|}{ Site of patch/Lokalizacja: } \\
\hline Head and neck/Głowa i szyja & $5(25 \%)$ & $4(20 \%)$ & 0.819 \\
\hline Trunk/Tułów & $4(20 \%)$ & $3(15 \%)$ & \\
\hline Limbs/Kończyny & $7(35 \%)$ & $10(50 \%)$ & \\
\hline Acral/Akralne & $4(20 \%)$ & $3(15 \%)$ & \\
\hline
\end{tabular}

sowano test $t$-Studenta $i$ test $\chi^{2}$. Za statystycznie istotne przyjęto wartości $p<0,05$.

\section{WYNIKI}

Rozkład pacjentów w grupie A i B pod względem wieku i płci był zbliżony $(p>0,05)$. Średni wiek w grupie A wynosił 33,4 $\pm 10,2$ roku, a w grupie B 31,7 $\pm 10,1$ roku (tab. 2). Bielactwo nabyte występowało częściej u kobiet - zarówno w grupie A (60\%), jak i B (65\%). Plamy depigmentacyjne były umiejscowione najczęściej w obrębie kończyn, zarówno w grupie A (55\%), jak i B (65\%). Kolejnymi lokalizacjami według częstości występowania były głowa i szyja oraz tułów.

\section{Ocena odpowiedzi na leczenie}

W grupie A repigmentację stwierdzono u 75\% (15) uczestników badania. Dobra odpowiedź na leczenie wystąpiła u 30\% (6), a słaba odpowiedź u 45\% (9) osób. U 5\% (5) osób nie wykazano repigmentacji.

W grupie B repigmentacja wystąpiła w różnym stopniu u wszystkich pacjentów. Korzystny wynik zabiegów (G3, G4) odnotowano u 60\% (12) pacjentów. Doskonałą odpowiedź na leczenie stwierdzono u $25 \%$ (5), a bardzo dobrą odpowiedź u 35\% (7) uczestników badania (tab. 3). Różnica w poprawie stanu skóry między grupami była znamienna statystycznie $(p<0,001)$.

\section{Działania niepożądane}

W grupie A łącznie 20\% (4) pacjentów zgłosiło ból podczas zabiegu. U 35\% (7) pacjentów pojawił się ru- 
Table 4. Comparison of results of this study with other studies

Tabela 4. Porównanie wyników przeprowadzonego badania z wcześniejszymi badaniami

\begin{tabular}{|c|c|c|}
\hline Study/Badanie & Author, year/Autor, rok & $\begin{array}{l}\text { Significant repigmentation at the end of study period/ } \\
\text { Znacząca repigmentacja po zakończeniu badania }\end{array}$ \\
\hline \multirow[t]{7}{*}{$\begin{array}{l}\text { Needling with 5\% 5FU/ } \\
\text { Nakłuwanie i 5\% 5FU }\end{array}$} & Current study/Aktualne badanie & $\begin{array}{l}25 \% \text { of patients at the end of } 6 \text { months } / 25 \% \text { pacjentów } \\
\text { po } 6 \text { miesiącach }\end{array}$ \\
\hline & $\begin{array}{l}\text { Zahra et al. [1 2] } 202 \text { I/Zahra i wsp. [1 2] } \\
202 \text { I }\end{array}$ & $\begin{array}{l}47 \% \text { of patients at the end of } 6 \text { months } / 47 \% \text { pacjentów } \\
\text { po } 6 \text { miesiącach }\end{array}$ \\
\hline & $\begin{array}{l}\text { Attwa et al. [20] 2019/Attwa i wsp. [20] } \\
2019\end{array}$ & $\begin{array}{l}3.7 \% \text { of patients at the end of } 3 \text { months } / 3,7 \% \\
\text { pacjentów po } 3 \text { miesiącach }\end{array}$ \\
\hline & $\begin{array}{l}\text { Mina et al. [26] 20 I 8/Mina i wsp. [26] } \\
2018\end{array}$ & $\begin{array}{l}48 \% \text { of patients at the end of } 6 \text { months } / 48 \% \text { pacjentów } \\
\text { po } 6 \text { miesiącach }\end{array}$ \\
\hline & $\begin{array}{l}\text { Shashikiran et al. [24] 2018/Shashikiran } \\
\text { i wsp. [24] } 2018\end{array}$ & $\begin{array}{l}49 \% \text { of patients at the end of } 6 \text { months } / 49 \% \text { pacjentów } \\
\text { po } 6 \text { miesiącach }\end{array}$ \\
\hline & $\begin{array}{l}\text { Santosh et al. [27] 2018/Santosh i wsp. } \\
\text { [27] } 2018\end{array}$ & $\begin{array}{l}60 \% \text { of patients at the end of } 3 \text { months/ } 60 \% \text { pacjentów } \\
\text { po } 3 \text { miesiącach }\end{array}$ \\
\hline & $\begin{array}{l}\text { Ghiya et al. [23] 2016/Ghiya i wsp. [23] } \\
2016\end{array}$ & $\begin{array}{l}60 \% \text { of patients at the end of } 6 \text { months } / 60 \% \text { pacjentów } \\
\text { po } 6 \text { miesiącach }\end{array}$ \\
\hline \multirow{2}{*}{$\begin{array}{l}\text { Laser dermabrasion } \\
\text { followed by topical 5FU/ } \\
\text { Dermabrazja laserowa + } \\
\text { miejscowa aplikacja 5FU }\end{array}$} & $\begin{array}{l}\text { George et al. [19] 2017/George i wsp. [19] } \\
2017\end{array}$ & $\begin{array}{l}40 \% \text { of patients at the end of } 3 \text { months } / 40 \% \text { pacjentów } \\
\text { po } 3 \text { miesiącach }\end{array}$ \\
\hline & $\begin{array}{l}\text { Mohamed et al. [ I 6] 2015/Mohamed } \\
\text { i wsp. [16] } 2015\end{array}$ & $\begin{array}{l}49.8 \% \text { of patients at the end of } 5 \text { months } / 49,8 \% \\
\text { pacjentów po } 5 \text { miesiącach }\end{array}$ \\
\hline
\end{tabular}

system to dramatically increase the bioavailability of topically applied agents and further to enhance their transcutaneous absorption delivering the molecule in

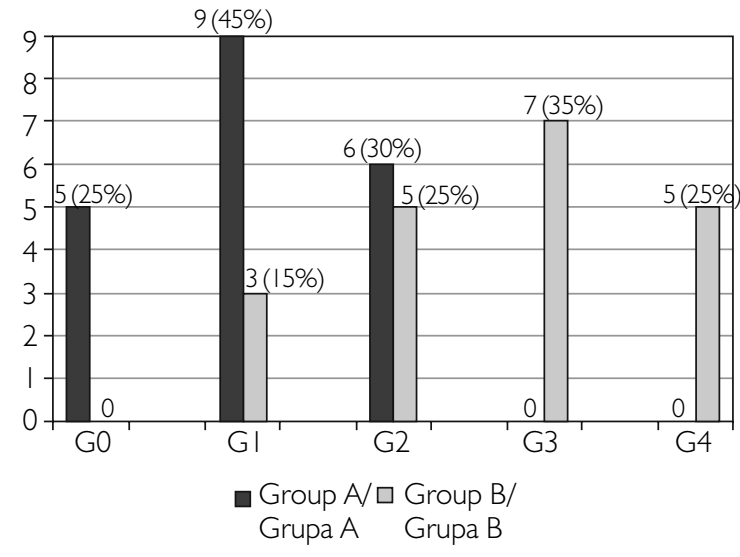

Figure I. Graph showing treatment outcomes in both the groups Rycina I. Wyniki leczenia w obu grupach mień, który ustąpił samoistnie w kolejnych 3 dniach. W grupie B wszyscy pacjenci zgłosili ból podczas zabiegu. Rumień wystąipił u 70\% (14) pacjentów, świąd u 15\% (3), a zjawisko koebneryzacji u $5 \%$ (1) pacjentów (tab. 4, ryc. 1-4).

\section{OMÓWIENIE}

Bielactwo wywołuje znaczące skutki psychologiczne u osób z tym schorzeniem, obniżając poziom ich samooceny [13]. We włoskim badaniu obejmującym 30 pacjentów z bielactwem u $10 \%$ wystąpiły zaburzenia depresyjne [14]. Dlatego też ważne jest, aby osobom z bielactwem zapewnić najbardziej odpowiednią, a jednocześnie efektywną kosztowo metodę leczenia, która daje zadowalające wyniki i sprzyja poprawie samooceny. Odpowiedni schemat terapii należy wybrać z szerokiego arsenału dostępnych metod, biorąc pod uwagę stabil-
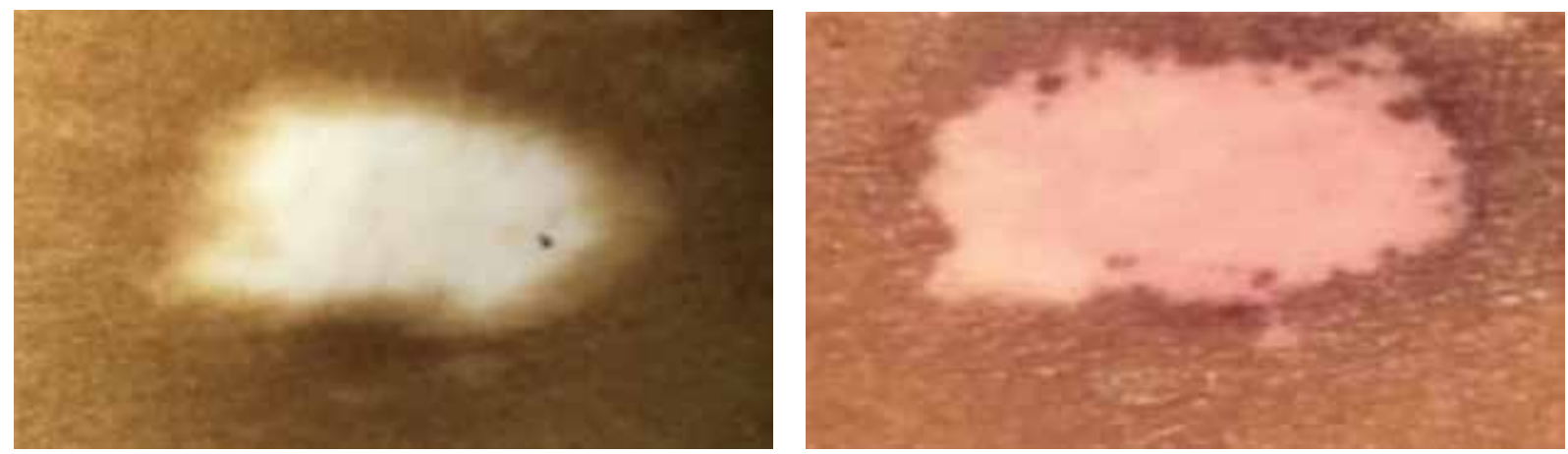

Figure 2. A 35-year-old female patient showing $G$ I response in group $A$

Rycina 2. Stopień odpowiedzi na leczenie GI u 35-letniej kobiety w grupie A 

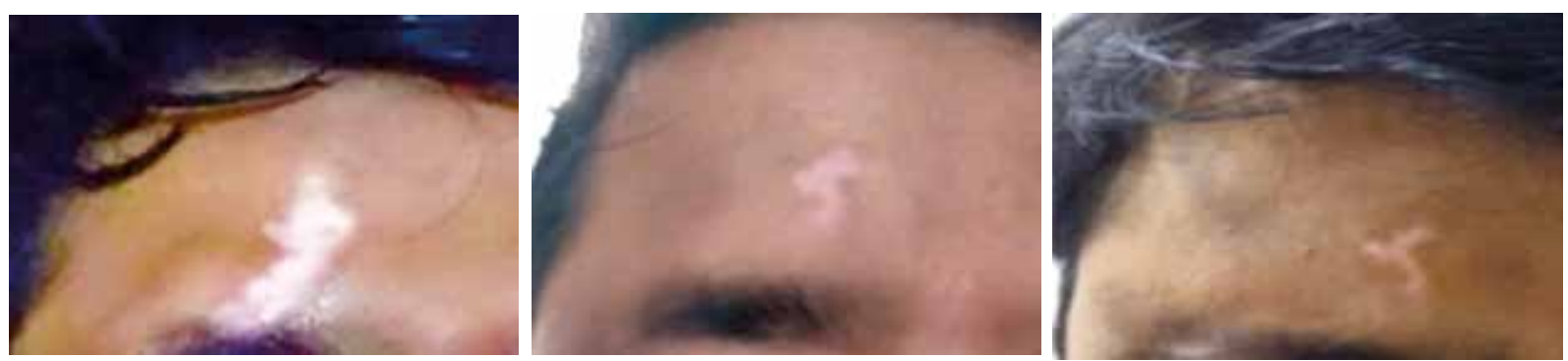

Figure 3. A 42-year-old male patient showing G4 response in group B

Rycina 3. Stopień odpowiedzi na leczenie G4 u 42-letniego mężczyzny w grupie B

adequate concentrations to melanocytes and keratinocytes [15]. In our study, we have done microneedling with a dermaroller of $1.5 \mathrm{~mm}$ needle thickness as an inexpensive, simple and quick office-based procedure.

The rationale for using $5 \mathrm{FU}$ as a treatment modality in vitiligo is the hyperpigmentation that commonly occurs as a side effect of 5FU treatment in cutaneous tumors [16]. Tsuji and Hamada [17] first introduced application of 5FU following therapeutic wounding where 5FU shows selective and differential cytotoxicity towards epidermal cells. Compared to the keratinocytes, melanocytes are less vulnerable to 5FU, which causes overstimulation of the follicular melanocytes, which migrate during epithelization to the surface, thereby inducing pigmentation [18]. Various in-vitro studies have shown that 5FU in low concentration selectively destroys keratinocytes in 3 weeks, whereas melanocytes continue to multiply and form pigment [19]. In this study, favorable outcome was noted in $60 \%$ of patients with microneedling followed by $5 F U$. The mode of repigmentation was predominantly follicular (small, brown, perifollicular macules which enlarged and coalesced) followed by extension of the pigment from the edges.

The mechanism of repigmentation following microneedling includes trauma induced inflammatory response leading to migration of active melanocytes during the healing phase, influx of cytokines like leukotriene C4 and D4, matrix metalloproteinases leading to stimulation of melanocytes in the periphery of the patch or outer root sheath of the pigmented hair [20] and by mechanical migration of the melanocytes so that they can serve as melanogenesis reservoir [21]. The better therapeutic efficacy of microneedling followed by 5-fluorouracil can be explained by the immunomodulatory effect where the inflammatory response creates a multicellular infiltrate where melanocytotoxic $\mathrm{T}$ cells become overruled [22]. Also, after microneedling 5FU is absorbed easily and it penetrates deeper to cause stimulation of amelanotic (inactive) melanocyte present at the outer root sheath of the hair follicle, which proliferates and migrates upwards and actively synthesizes melanin, which migrates upwards to reach the skin surface. This appears as perifollicular pigmen-

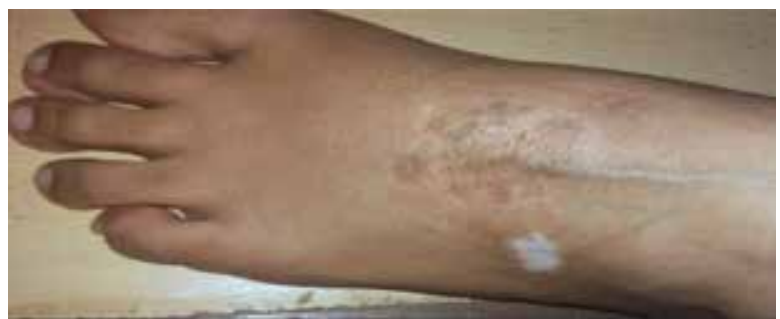

Figure 4. A 20-year-old male showing koebnerization after 3 months of treatment in group $B$

Rycina 4. Zjawisko koebneryzacji u 20-letniego mężczyzny w grupie B po 3 miesiącach leczenia

ność przebiegu i charakter choroby, stopień zajęcia skóry, wiek pacjenta itp.

Mikronakłuwanie jest techniką wykorzystywaną w leczeniu różnych dermatoz, a także przy podawaniu leków jako metoda, która radykalnie zwiększa biodostępność miejscowo aplikowanych środków terapeutycznych oraz nasila ich wchłanianie przez skórę, dostarczając lek w odpowiednim stężeniu do melanocytów i keratynocytów [15]. W naszym badaniu wykonano niedrogi, prosty i szybki zabieg polegający na mikronakłuwaniu skóry dermarollerem o grubości igieł 1,5 mm.

Uzasadnieniem dla stosowania 5FU w leczeniu bielactwa nabytego jest hiperpigmentacja często występująca jako efekt uboczny terapii opartej na 5FU u pacjentów z nowotworami skóry [16]. Tsuji i Hamada [17] po zaobserwowaniu, że 5FU wykazuje selektywną i zróżnicowaną cytotoksyczność względem komórek naskórka po raz pierwszy zastosowali lek po nakłuwaniu skóry. W porównaniu z keratynocytami, melanocyty są mniej wrażliwe na działanie 5FU. W rezultacie lek wywołuje wzmożone pobudzenie melanocytów mieszkowych, które w procesie epitelializacji migrują na powierzchnię skóry, co wywołuje pigmentację [18]. W różnych badaniach in vitro wykazano, że 5FU w niskim stężeniu selektywnie niszczy keratynocyty w czasie 3 tygodni, natomiast nie wpływa na melanocyty, które nadal namnażają się i wytwarzają melaninę [19]. W przeprowadzonym badaniu korzystny wynik leczenia stwierdzono u $60 \%$ pacjentów, u których wykonano mikronakłuwanie, a następnie aplikowano 5FU. Mechanizm re- 
tation, which gradually enlarges to cover the whole area [16]. Also 5FU competitively inhibits thymidylate synthetase and damages some inhibitory cells/agents that may be the reason for melanin destruction producing vitiligo [20].

A comparative study done by Attwa et al. [20] in 27 patients showed significantly higher efficacy in patients with microneedling with 5FU compared to 5FU alone.

A randomized controlled trial by Zahra et al. [12] in 60 patients compared the efficacy of 5FU with microneedling versus topical 5FU and found significantly better results in patients with microneedling and 5FU with excellent repigmentation in $47 \%$ with microneedling with $5 \mathrm{FU}$ and only $4.3 \%$ in topical 5FU only.

Ghiya et al. [23] used 5FU with microneedling and repigmentation was noted in $67.24 \%$ but their study included only children from 5 to 14 years.

There were no significant side effects noted in both groups and this was in concordance with a study done by Shashikiran et al. [24]. However, a study conducted by Sethi et al. [25] combining dermabrasion with 5FU, noted serous discharge, pseudomembrane formation and hypertrophic scarring.

Previous studies have used 5FU with dermabrasion, dermapen and lasers, which need special expensive equipment and a special clinic setup. Carbon dioxide laser has been used instead of microneedling previously with 5FU by Mohamed et al. [16], which showed $49.8 \%$ improvement but our study showed better results with cost-effective modality with less downtime.

A limitation of our study was a short follow-up period and only a single blinded design. In this study, we did not evaluate the treatment efficacy on mucosal vitiligo.

\section{CONCLUSIONS}

We found that microneedling followed by topical application of 5FU can be used as a cost-effective, simple, well-tolerated, and easy-to-perform therapy in patients not responding to conventional therapy.

\section{CONFLICT OF INTEREST}

The authors declare no conflict of interest. pigmentacji był głównie mieszkowy (powstawanie niewielkich, brązowo zabarwionych plamek wokół mieszków włosowych, które następnie ulegały powiększaniu i zlewaniu). Następnie obserwowano rozprzestrzenianie się barwnika od krawędzi.

Mechanizm repigmentacji po mikronakłuwaniu obejmuje wywołaną urazem odpowiedź zapalną, która prowadzi do migracji aktywnych melanocytów w fazie gojenia oraz napływu cytokin (m.in. leukotrienu C4 i D4) i metaloproteinaz macierzy. Mechanizm ten pobudza melanocyty na obwodzie zmian skórnych lub w zewnętrznej osłonce mieszków włosowych [20] i prowadzi do mechanicznego przemieszczania się melanocytów, które mogą służyć jako rezerwuar w procesie melanogenezy [21]. Lepszą skuteczność terapeutyczną mikronakłuwania w połączeniu z 5FU można wyjaśnić procesem immunomodulacyjnym. W jego przebiegu odpowiedź zapalna prowadzi do powstania wielokomórkowego nacieku, w którym zahamowaniu ulega aktywność limfocytów T [22]. Ponadto 5FU aplikowany po mikronakłuwaniu skóry łatwo się wchłania i wnika głębiej w skórę, pobudzając nieprodukujące melaninę melanocyty w zewnętrznej osłonce mieszka włosowego, które ulegają proliferacji i migracji ku górze. Melanocyty te w sposób aktywny wytwarzają melaninę, która również przemieszcza się do powierzchni skóry. Jest to proces pigmentacji okołomieszkowej, która stopniowo rozprzestrzenia się także na inne obszary skóry [16]. Ponadto 5FU kompetycyjnie hamuje syntazę tymidylanową i uszkadza niektóre komórki lub substancje blokujące, które mogą odpowiadać za niszczenie melaniny skutkujące rozwojem bielactwa nabytego [20].

W badaniu porównawczym Attwa i wsp. [20] przeprowadzonym u 27 pacjentów wykazano znamiennie wyższą skuteczność mikronakłuwania w skojarzeniu z 5FU w porównaniu z 5FU.

$\mathrm{W}$ randomizowanym kontrolowanym badaniu Zahra i wsp. [12] w grupie 60 pacjentów porównano skuteczność $5 F U$ w połączeniu z mikronakłuwaniem oraz samej miejscowej aplikacji 5FU. Znamiennie lepsze wyniki otrzymano u pacjentów, u których zastosowano mikronakłuwanie i 5FU. Doskonałą repigmentację osiągnięto u $47 \%$ uczestników poddawanych mikronakłuwaniu i miejscowemu leczeniu 5FU i zaledwie 4,3\% pacjentów, u których aplikowano 5FU bez wcześniejszego mikronakłuwania.

W badaniu Ghiya i wsp. [23], w którym oceniano skuteczność 5FU w skojarzeniu z mikronakłuwaniem, repigmentację stwierdzono w $67,24 \%$ przypadków. Należy jednak zaznaczyć, że było to badanie przeprowadzone w grupie obejmującej wyłącznie dzieci w wieku od 5 do 14 lat. 
W żadnej z grup w naszym badaniu nie stwierdzono istotnych działań niepożądanych. Jest to wynik zgodny z doniesieniami zawartymi w publikacji Shashikiran i wsp. [24]. W badaniu przeprowadzonym przez Sethiego i wsp. [25], w którym stosowano metodę dermabrazji w połączeniu z 5FU, u pacjentów obserwowano wydzielinę surowiczą, tworzenie się błon rzekomych oraz blizny przerostowe.

We wcześniejszych badaniach stosowano 5FU w skojarzeniu z dermabrazją, laseroterapią i demapenem. Są to jednak metody, które wymagają specjalistycznego, drogiego sprzętu oraz określonych warunków prowadzenia zabiegu. W badaniu Mohameda i wsp. [16] stosowano 5FU w skojarzeniu z zabiegiem laserem frakcyjnym $\mathrm{CO}_{2}$. Poprawę stanu skóry odnotowano w 49,8\% przypadków. W naszym badaniu otrzymaliśmy lepsze wyniki przy zastosowaniu tańszej metody, która wiąże się z mniejszą liczbą przestojów.

Ograniczeniem przedstawionego badania był krótki czas obserwacji i schemat badawczy z pojedynczym zaślepieniem. Ponadto w przeprowadzonym badaniu nie oceniano skuteczności leczenia bielactwa nabytego umiejscowionego w obrębie błon śluzowych.

\section{WNIOSKI}

Wyniki badania wskazują, że mikronakłuwanie skóry, a następnie miejscowa aplikacja 5FU może stanowić prostą w zastosowaniu, efektywną kosztowo i dobrze tolerowaną metodę leczenia bielactwa nabytego u pacjentów, którzy nie reagują na tradycyjną terapię.

\section{KONFLIKT INTERESÓW}

Autorzy nie zgłaszają konfliktu interesów.

\section{References}

Piśmiennictwo

1. Iriarte C., Awosika O., Pardo M.R., Ehrlich A.: Review of applications of microneedling in dermatology. Clin Cosmet Inves Dermatol 2017, 10, 289-298.

2. Lee J.C., Daniels M.A., Roth M.Z.: Mesotherapy, microneedling and chemical peels. Clin Plast Surg 2016, 43, 583-595.

3. Doddaballapur S.: Microneedling with dermaroller. J Cutan Aesthet Surg 2009, 2, 110-111.

4. Salloum A., Bazzi N., Maalouf D., Habre M.: Microneedling in vitiligo: a systematic review. Dermatol Ther 2020, 33 , e14297.

5. Grimes P.E., Miller M.M.: Vitiligo: patient stories, self-esteem and the psychological burden of disease. Int J Women Dermatol 2018, 4, 32-37.

6. Konstantinova V.A., Olisova O.Y., Gladko V.V., Burova E.P.: Vitiligo - new treatment approach. Clin Cosmet Investig Dermatol 2019, 12, 911-917.

7. Dillon A.B., Sideris A., Hadi A., Elbuluk N.: Advances in vitiligo: an update on medical and surgical treatments. J Clin Aesthet Dermatol 2017, 10, 15-28.

8. Wassef C., Lombardi A., Khokher S., Rao B.K.: Vitiligo surgical, laser and alternative therapies: a review and case series. J Drugs Dermatol 2013, 12, 685-691.

9. AIJasser M.I., Altalhab S.: Controlled depth of needling using simple injection needles. J Am Acad Dermatol 2020, 83, e331-e332. 
10. Giorgio C.M., Caccavale S., Fulgione E., Moscarella E., Babino G., Argenziano G.: Efficacy of microneedling and photodynamic therapy in vitiligo. Dermatol Surg 2019, 45, 1424-1426.

11. Abdelwahab M., Salah M., Samy N., Rabie A., Farrag A.: Effect of topical 5-flurouracil alone versus its combination with Er:YAG (2940nm) laser in treatment of vitiligo. Clin Cosmet Invest Dermatol 2020, 13, 77-85.

12. Zahra F.T., Adil M., Amin S.S., Mohtshim M., Bansal R., Khan H.Q.: Efficacy of topical 5\% 5-flurouracil with microneedling versus 5\% 5-flurouracil alone in stable vitiligo: a randomized controlled study. J Cutan Aesthet Surg 2020, 13, $197-203$.

13. Pahwa P., Mehta M., Khaitan B.K., Sharma V.K., Ramam M.: The psychosocial impact of vitiligo on Indian patients. Indian J Dermatol Venereol Leprol 2013, 28, 419-423.

14. Sharma N., Koranne R.V., Singh R.K.: Psychiatric morbidity in psoriasis and vitiligo: a comparative study. J Dermatol 2001, $28,419-423$.

15. Malik N., Singh Y., Goyal T.: A simple office-based procedure for patients with extensive vitiligo. J Am Acad Dermatol 2016, 75, 195-197.

16. Mohamed H.A., Mohamed G.F., Gomaa A.H., Eyada M.M.K.: Carbon dioxide laser plus topical 5-flurouracil: a new combination therapeutic modality for acral vitiligo. J Cosmet Laser Ther 2015, 17, 216-223.

17. Tsuji T., Hamada T.: Topically administered flurouracil in vitiligo. Arch Dermatol 1983, 119, $722-727$.

18. Tsuji T., Karasek M.A.: Differential effects of 5-flurouracil on human skin melanocytes and malignant melanoma cells in vitro. Acta Derm Venereol 1986, 66, 474-478.

19. George M., Mallikarjun M., Manjunath P., Gangadhar B.: Efficacy of laser dermabrasion followed by topical 5 flurouracil in the treatment of stable vitiligo. Int J Health Sci Res 2017, 7, 144-147.

20. Attwa E.M., Khashaba S.A., Ezzat N.A.: Evaluation of the additional effect of 5 flurouracil to needling in the treatment of localized vitiligo. J Cosmet Dermatol 2020, 19, 1473-1478.

21. Khasaba S., Elkot R.A., Ibrahim A.M.: Efficacy of NBUVB, microneedling with triamcinolone acetonide and a combination of both modalities in the treatment of vitiligo: a comparative study. J Am Acad Dermatol 2018, 79, $365-367$.

22. Anbar T., Westerhof W., Abdel Rahman A., El-Khayyat M., El-Metwally Y.: Treatment of periungual vitiligo with erbium YAG plus 5-flurouracil: a left to right comparative study. J Cosmet Dermatol 2006, 5, 135-139.

23. Ghiya B.C., Soni P., Singrodia A.K., Chhabra S., Mehta R.D., Bai J.S.: Comparative evaluation of therapeutic efficacy of microneedling alone or microneedling combined with topical 5-flurouracil in localized stable childhood vitiligo. Adv Hum Biol 2016, 6, 25-28.

24. Shashikiran A.R., Gandhi S., Murugesh S.B., Kusagur M., Sugareddy: Efficacy of topical 5\% flurouracil needling in vitiligo. Indian J Dermatol Venereol Leprol 2018, 84, e67-e69.

25. Sethi S., Mahajan B.B., Gupta R.R., Ohri A.: Comparative evaluation of therapeutic efficacy of dermabrasion, dermabrasion combined with topical 5\% 5-flurouracil cream and dermabrasion combined with topical placentrex gel in localized stable vitiligo. Int J Dermatol 2007, 46, 875-879.

26. Mina M., Elgarhy L., Al-Saeid H., Ibraim Z.: Comparison between the efficacy of microneedling combined with 5-flurouracil vs. microneedling with tacrolimus in the treatment of vitiligo. J Cosmet Dermatol 2018, 17, 744-751.

27. Santosh S.K., Sushantika, Mohan L., Gupta A.K., Mohammad A., Kumar N.: Treatment of vitiligo with 5-flurouracil after microneedling of the lesion. Int J Sci Stud 2018, 5, 125-127.

Received: 19.04 .2021

Accepted: 6.09.2021

Otrzymano: $19.04 .2021 \mathrm{r}$.

Zaakceptowano: 6.09.2021 r.

How to cite this article

Jartarkar S.R., Manjunath K.G., Harini S., Sampath S.: A single blind active controlled study to compare the efficacy of microneedling and microneedling with 5-flurouracil in treatment of stable vitiligo. Dermatol Rev/Przegl Dermatol 2021, 108, $275-284$. DOI: https://doi.org/10.5114/dr.2021.111306. 